\title{
Synthesis and Detection of Publication Bias in Relationship between Motivation and Teacher Performance: A Meta-analysis Review
}

\author{
Jefri Mailool $^{1,2, *}$, Heri Retnawati ${ }^{2}$, Heldy Jerry Rogahang ${ }^{1}$, Wolter Weol ${ }^{1}$, Mercy W. K Waney ${ }^{1}$ \\ ${ }^{1}$ Department of Christian Education, Manado State Christian Institute (IAKN Manado), Indonesia \\ ${ }^{2}$ Department of Educational Research and Evaluation, Yogyakarta State University, Indonesia
}

Received August 12, 2020; Revised September 14, 2020; Accepted October 19, 2020

\section{Cite This Paper in the following Citation Styles}

(a): [1] Jefri Mailool, Heri Retnawati, Heldy Jerry Rogahang, Wolter Weol, Mercy W.K Waney, "Synthesis and Detection of Publication Bias in Relationship between Motivation and Teacher Performance: A Meta-analysis Review," Universal Journal of Educational Research, Vol. 8, No. 11B, pp. 6208-6216, 2020. DOI: 10.13189/ujer.2020.082259.

(b): Jefri Mailool, Heri Retnawati, Heldy Jerry Rogahang, Wolter Weol, Mercy W.K Waney (2020). Synthesis and Detection of Publication Bias in Relationship between Motivation and Teacher Performance: A Meta-analysis Review. Universal Journal of Educational Research, 8(11B), 6208-62162. DOI: 10.13189/ujer.2020.082259.

Copyright $(2020$ by authors, all rights reserved. Authors agree that this article remains permanently open access under the terms of the Creative Commons Attribution License 4.0 International License

\begin{abstract}
The relationship between motivation and teacher performance has been extensively investigated by using various models of relationship analysis. As a result, the relationship between the two variables is relatively poorly understood and requires separate analysis to ascertain the extent of the relationship between the two variables. In addition, a number of studies have reported that motivation has a significant relationship with teacher performance. However, the accuracy of the information reported by these studies is an important aspect to explore to ensure that there is no publication bias. This research aims to analyze the relationship between motivation and teacher performance based on a meta-analysis review of a number of published studies. The research data used were 30 correlational research results from journal articles published from 2010 to 2019 . The random effects model was used as an effect size in this meta-analysis study. The effect summary results show that there is a significant relationship between motivation and teacher performance with an $r$ coefficient of 0.446 and the confidence interval is moderate category with a value range between 0.371 0.515. By using the Trim and Fill method in this meta-analysis procedure, it was found that this research did not indicate publication bias. The results of this research can be an important reference for education providers, especially school administrators, to plan strategies for increasing school productivity. Motivation can be a potential trigger factor for improving teacher performance.
\end{abstract}

Thus, school administrators can design appropriate motivational strategies to improve their teacher performance.

Keywords Meta-analysis, Motivation, Teacher Performance

\section{Introduction}

Motivation theory existed almost eight decades ago and has undergone many developments over time. The development of motivation theory can be traced from a number of motivational theories which include: the hierarchy of needs theory [1], X and Y theories [2], expectancy theory [3], the theory of the need for achievement [4], two-factor theory [5], task motivation and incentive theory [6], ERG theory [7], and Self-Determination Theory [8]. Until now, motivation was seen as an interesting classic issue and was widely discussed in a number of studies in psychology, management, and even education ([9]; [10]; [11]).

The issue of motivation has been widely studied, especially in relation to human resource management and organizational development. Motivation has been shown to have an important role in increasing individual performance and organizational productivity [12]. In the field of 
education, the research of motivation is often associated with improving educational performance, both individually and institutionally. In smaller areas of education such as at the school level, research of motivation is often directed at the issue of improving teacher performance. However, on the other hand, teacher work motivation is also an important issue that can be improved through proper organizational management at the school level [13].

Motivation is an important factor that determines the achievement of one's work. [14] suggests that motivation becomes a force that energizes, navigates, and maintains individual actions. A similar view was expressed by [15] that motivation is a psychological process that determines the direction, intensity, and persistence of one's actions in relation to their work. Individual actions that are driven by certain motivations have the potential to produce better performance. In the organizational context, individuals who have strong work motivation will be more effective in doing their work compared to individuals who lack motivation. This is in line with the views of [16] which state that motivational control over behavior is achieved largely through the allocation of resources across all actions. Thus it can be concluded that behavior can result from actions that are navigated by motivation.

Motivation is a psychological process that encourages individuals to act towards certain goals that can affect the behavior produced by the individual. [17] suggested that motivation has an important effect on the quality of one's work and behavior. In the context of education in the scope of schools, teacher behavior that is relevant to the needs and achievement of school goals can be assessed as teacher performance.

Teacher performance is an interesting problem to learn even though it is not new in the scope of educational research [18]. Many educational researchers have explored the problem of teacher performance in the past ([19]; [20]; [21]; [22]; [23]; [24]). Contributions made by teacher performance are important for improving the quality of education. Therefore, the problem of teacher performance has always been an important research material among educational academics to date ([25]; [26]). In addition, today's rapidly developing information systems have made it possible for information transparency in the implementation of educational practices in schools [27]. With the transparency of this information, the process of monitoring teacher performance is easier to do. This situation requires every school leader to work hard in overcoming teacher performance problems [28].

Performance is defined as the results of work done by a person or organization within a certain period ([29]; [30]). This definition of performance is only limited to the context of the results and does not represent overall aspects of performance. [31] offers a more comprehensive definition of performance. Performance can be understood in the context of behavior and also results [32]. According to [33], a person's behavior can be considered as an outcome because it results from a person's mental and physical processes when applied to a task. With this rationale, [28] assume that to measure one's performance can refer to the behavior and results of one's thoughts. A similar opinion was expressed by [32] that performance is the result and behavior of a person that is relevant to organizational goals. By understanding these concepts, teacher performance can be understood as any behavior or teacher work that is relevant to the goals of the school organization.

Themes on teacher performance have resulted in research that has explored many processes and outcomes from various theoretical perspectives. The relationship between motivation and teacher performance has been extensively investigated by various relationship analysis models, both in the position as exogenous and endogenous variables, and its position as an intermediate variable that bridges the relationship between variables. As a result, the relationship between these two variables is relatively poorly understood and requires a separate analysis to ascertain the extent of the relationship between these two variables. In addition, a number of studies have reported that motivation has a significant relationship with teacher performance. However, the accuracy of the information reported by this research is an important aspect to explore in ensuring that publication bias does not occur in it. Therefore, this research aims to reveal two things:

1) How is the relationship between motivation and teacher performance based on the synthesis of a number of published research?

2) Is there a publication bias about the relationship between motivation and teacher performance?

\section{Materials and Methods}

This research is a synthesis of a number of correlation studies with the use of meta-analysis. The data collected in this research were obtained from a number of research articles in scientific journals that had been published from 2010 to 2019. These articles were written in Indonesian and English. For the procedure of finding articles in this research generally the researcher uses the Google Search Engine and searches on the Open Journal System from various universities. A total of 107 research articles that examined the relationship between motivation and teacher performance were collected by the researcher. However, after verifying only 30 articles were eligible for research and the remaining 77 articles were not used because the required data such as $\mathrm{r}, \mathrm{F}$, $\mathrm{t}$, or even $\mathrm{N}$ values were not presented in these articles. In addition, there are also research articles that use a qualitative approach so that they do not meet the requirements to be analyzed by this research method. The sample of this research was teachers at the kindergarten, primary school, junior high school, senior high school / vocational school level in public and private schools. The type of meta-analysis used in this research is correlation meta-analysis. 
The researcher calculates the effect size and standard error of each research article that has been verified and meets the requirements for further analysis. Before calculating the effect size, the $F$ value or even the $t$ value is converted to the r-value with the consideration that sometimes found in research data that does not provide or display the data needed comprehensively, such as there is an $\mathrm{F}$ value but does not provide information about the r-value.

r-values for 30 correlation research results in this research are presented in full in Table 1. For articles that do not include $r$ values in their research results, r-values can be calculated based on the following equation:

$$
\begin{gathered}
\mathrm{t}=\sqrt{\mathrm{F}} \\
\mathrm{r}=\mathrm{t} /\left(\sqrt{\mathrm{t}^{2}}+\mathrm{N}-2\right)
\end{gathered}
$$

After calculating the effect size, the next step is the analysis procedure to determine the summary effect. The summary effect in this research uses a random-effect model. The random-effect model was used in this research by considering the assumption that the studies analyzed had different true-effect [33]. The intended true-effect here is the actual effect size at the population level.

Data processing and forest-plot making in this research uses the JASP 0.9.0.1 application.

\begin{tabular}{|c|c|c|c|c|c|c|c|c|}
\hline Studies & Researcher & $\mathbf{N}$ & Sample & $\mathbf{F}$ & $\mathbf{t}$ & $\mathbf{r}$ & ES & SE \\
\hline Studies 1 & [34] & 30 & Senior High School Teacher & - & 0.68 & 0.127 & 0.128 & 0.192 \\
\hline Studies 2 & {$[35]$} & 150 & Senior High School Teacher & - & - & 0.305 & 0.315 & 0.082 \\
\hline Studies 3 & {$[36]$} & 60 & Junior High School Teacher & - & - & 0.57 & 0.648 & 0.132 \\
\hline Studies 4 & [37] & 177 & Senior High School Teacher & - & - & 0.292 & 0.301 & 0.076 \\
\hline Studies 5 & {$[38]$} & 110 & Certified Teacher & - & - & 0.636 & 0.751 & 0.097 \\
\hline Studies 6 & [39] & 35 & Junior High School Teacher & - & 1.926 & 0.318 & 0.329 & 0.177 \\
\hline Studies 7 & [40] & 229 & Senior High School Teacher & - & - & 0.16 & 0.161 & 0.067 \\
\hline Studies 8 & [41] & 39 & Junior High School Teacher & - & 2.739 & 0.411 & 0.437 & 0.167 \\
\hline Studies 9 & {$[42]$} & 71 & Junior High School Teacher & - & - & 0.381 & 0.401 & 0.121 \\
\hline Studies 10 & [43] & 88 & Kindergarten Teacher & - & - & 0.565 & 0.640 & 0.108 \\
\hline Studies 11 & [44] & 82 & Senior High School Teacher & & & 0.408 & 0.433 & 0.113 \\
\hline Studies 12 & {$[45]$} & 46 & Senior High School Teacher & - & - & -0.092 & -0.092 & 0.152 \\
\hline Studies 13 & {$[46]$} & 60 & Vocational Teacher & - & - & 0.063 & 0.063 & 0.132 \\
\hline Studies 14 & [47] & 63 & Primary School Teacher & - & - & 0.58 & 0.662 & 0.129 \\
\hline Studies 15 & [48] & 110 & Primary School Teacher & - & - & 0.675 & 0.820 & 0.097 \\
\hline Studies 16 & [49] & 156 & Senior High School Teacher & - & - & 0.732 & 0.933 & 0.081 \\
\hline Studies 17 & {$[50]$} & 33 & Vocational Teacher & - & - & 0.634 & 0.748 & 0.183 \\
\hline Studies 18 & [51] & 202 & Junior High School Teacher & - & 6.29 & 0.406 & 0.431 & 0.071 \\
\hline Studies 19 & {$[52]$} & 110 & Senior High School Teacher & - & - & 0.296 & 0.305 & 0.097 \\
\hline Studies 20 & [53] & 170 & Primary School Teacher & - & - & 0.659 & 0.791 & 0.077 \\
\hline Studies 21 & [54] & 192 & Senior High School Teacher & - & - & 0.533 & 0.594 & 0.073 \\
\hline Studies 22 & [55] & 97 & Vocational Teacher & 7.51 & 3.677 & 0.353 & 0.369 & 0.103 \\
\hline Studies 23 & {$[56]$} & 87 & Madrasa Teacher & 4.906 & 2.215 & 0.234 & 0.238 & 0.109 \\
\hline Studies 24 & [57] & 57 & Senior High School Teacher & - & 7.377 & 0.705 & 0.877 & 0.136 \\
\hline Studies 25 & [58] & 400 & Junior High School Teacher & - & - & 0.306 & 0.316 & 0.050 \\
\hline Studies 26 & [59] & 33 & Junior High School Teacher & - & 2.234 & 0.372 & 0.391 & 0.183 \\
\hline Studies 27 & {$[60]$} & 54 & Kindergarten Teacher & & - & 0.529 & 0.589 & 0.140 \\
\hline Studies 28 & [61] & 83 & Primary School Teacher & - & - & 0.493 & 0.540 & 0.112 \\
\hline Studies 29 & {$[62]$} & 63 & Foundation Teacher & 14.758 & 3.323 & 0.392 & 0.414 & 0.129 \\
\hline Studies 30 & [63] & 65 & Junior High School Teacher & - & - & 0.579 & 0.661 & 0.127 \\
\hline
\end{tabular}

Table 1. Transform $F$ values into $t$ and $r$ values and Effect Size and Standard Error 


\section{Results and Discussion}

The results of the conversion of the values of $F$ and $t$ to $r$ as well as the results of the calculation of the effect size and standard error of 30 correlation research for this research can be seen in Table 1 .

The statistical values in table 1 become the main data in this meta-analysis process to obtain information about the summary of the effects of the research that have been collected. In addition, the statistical values in table 1 are also the main data used to detect publication bias in this research.

\subsection{Summary Effect Using the Random Effect Model}

Based on the results of calculations using a random effect model where the number $\mathrm{k}=30$, obtained $\mathrm{p}$-value $<0.001$ for parameter $\mathrm{Q}=171.2$ with free degrees $(\mathrm{df})=29$. With p-value $<0.05$ (for a significance level of $95 \%$ ), then $\mathrm{H} 0$ is rejected so it can be concluded that $\theta$ is not equal to 0 , which means there is a significant relationship between motivation and teacher performance. For the estimated standard error (SEM) value obtained 0.0457 and the $\mathrm{Z}$ value of 10.451 where the $Z$ value is only to confirm the omnibus test (omnibus test of coefficient models) in Table 2. The results of these calculations are presented in Table 2 and Table 3 below.

To prove whether the effect size in this research is different, a heterogeneity test is performed. Based on the heterogeneity effect size test with several parameters, then obtained $\tau^{2}$ and $\tau$ are greater than $0\left(\tau^{2}\right.$ and $\left.\tau>0\right)$ with values of both of them at 0.0486 for $\tau^{2}$ and 0.2206 for $\tau$. With this result, $\mathrm{H} 0$ is rejected, so it can be concluded that the effect size of each research used in this meta-analysis is heterogeneous. Whereas the parameter $I^{2}$ was $82.8419 \%$ which showed that the effect size between research was heterogeneous. The heterogeneity test results are presented in Table 4 below.

Table 2. Significance of Effect Size

\begin{tabular}{lccc}
\hline \multicolumn{4}{c}{ Fixed and Random Effects } \\
\hline & $Q$ & $d f$ & $p$ \\
\hline Omnibus test of Model Coefficients & 109.2 & 1 & $<.001$ \\
\hline Test of Residual Heterogeneity & 171.2 & 29 & $<.001$ \\
\hline Note. $p$-values are approximate. & & & \\
\hline
\end{tabular}

Table 3. Estimated Coefficient

\begin{tabular}{lcccc}
\hline & Estimate & Standard Error & $z$ & $p$ \\
\hline intrcpt & 0.4777 & 0.0457 & 10.451 & $<.001$ \\
\hline
\end{tabular}

Note. Wald test.

Table 4. Estimated Coefficient

\begin{tabular}{ll}
\hline Estimate & \\
\hline$\tau^{2}$ & 0.0486 \\
\hline$\tau$ & 0.2206 \\
\hline$I^{2}(\%)$ & 82.8419 \\
\hline$H^{2}$ & 5.8281 \\
\hline
\end{tabular}

For Forest Plot Summary results with random effects models can be seen in the following figure 1 .

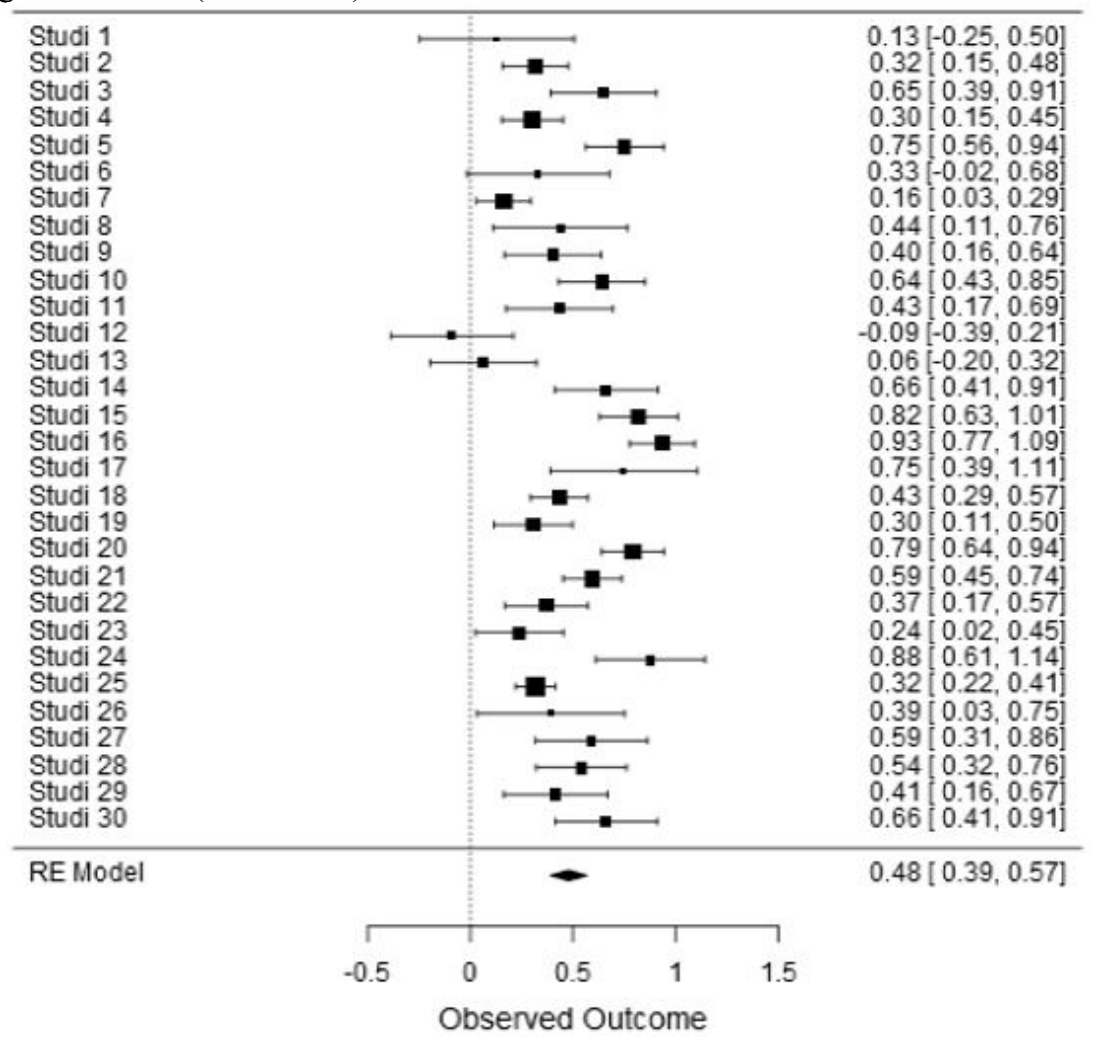

Figure 1. Forest Plot Summary for Random Effect 
Based on the forest plot in Figure 1, the average weighted effect size (M) is 0.48 with a lower limit of confidence interval M (LLM) is 0.39 , and the upper limit of confidence interval M (ULM) is 0.57. To obtain the correlation value from this meta-analysis research, the average weighted effect size $(\mathrm{M})$ value is converted to the correlation coefficient $r$. The same treatment is also applied at the confidence interval, where LLM is converted to LLr, and ULM is converted to ULr. Each conversion equation for values of $\mathrm{M}$ to $\mathrm{r}$ and their confidence intervals is calculated by the following equation:

$$
\begin{aligned}
r & =\mathrm{e}^{(2 \times M-1)} / \mathrm{e}^{(2 \times \mathrm{M}+1)} \\
\mathrm{LLr} & =\mathrm{e}^{(2 \times \mathrm{LLM}-1)} / \mathrm{e}^{(2 \times \mathrm{LLM}+1)} \\
\mathrm{ULr} & =\mathrm{e}^{(2 \times \mathrm{ULM}-1)} / \mathrm{e}^{(2 \times \mathrm{ULM}+1)}
\end{aligned}
$$

Based on the results of calculations using equations 3, 4, and 5 , the correlation coefficient $(\mathrm{r})$ is 0.446 . This coefficient value indicates that the correlation between motivation and teacher performance is in the 'moderate' category [64]. Whereas the confidence interval is in the range between $0.371-0.515$. This moderate category indicates that motivation has an important role in increasing teacher performance, but it is not entirely dominant affecting teacher performance because there are other variables that also influence teacher performance, such as the ability variable. This is supported by [65] who argues that ability is part of an individual aspect that influences a person's behavior in carrying out their duties or work.

\subsection{Publication Bias}

Publication bias occurs when the publication of research depends on the nature and direction of the results so the published research may be systematically different from unpublished research [66]. According to [67] that research with statistically significant or positive results are more likely to be published than non-significant or negative results.

In the process of research dissemination, bias can be included intentionally or unintentionally, knowingly, or unknowingly [67]. Researchers, research sponsors, peer reviewers, and journal editors can influence the research dissemination process. While the consequences of publication bias are the results of misleading estimates for treatment effects and relationships between research variables. This publication bias also impacts on the inaccuracy of information produced so that the published literature may not represent the research that has been done [33].

To detect whether publication bias occurs in this meta-analysis research, the Funnel Plot method and Trim-Fill analysis are used. The results of the analysis of these two methods as shown in Figures 2 and 3.

The visualization resulting from the Funnel Plot method in Figure 2 shows the shape of the Funnel Plot which is relatively symmetrical with the distribution of points that tends to be evenly distributed at the top, middle, and bottom.

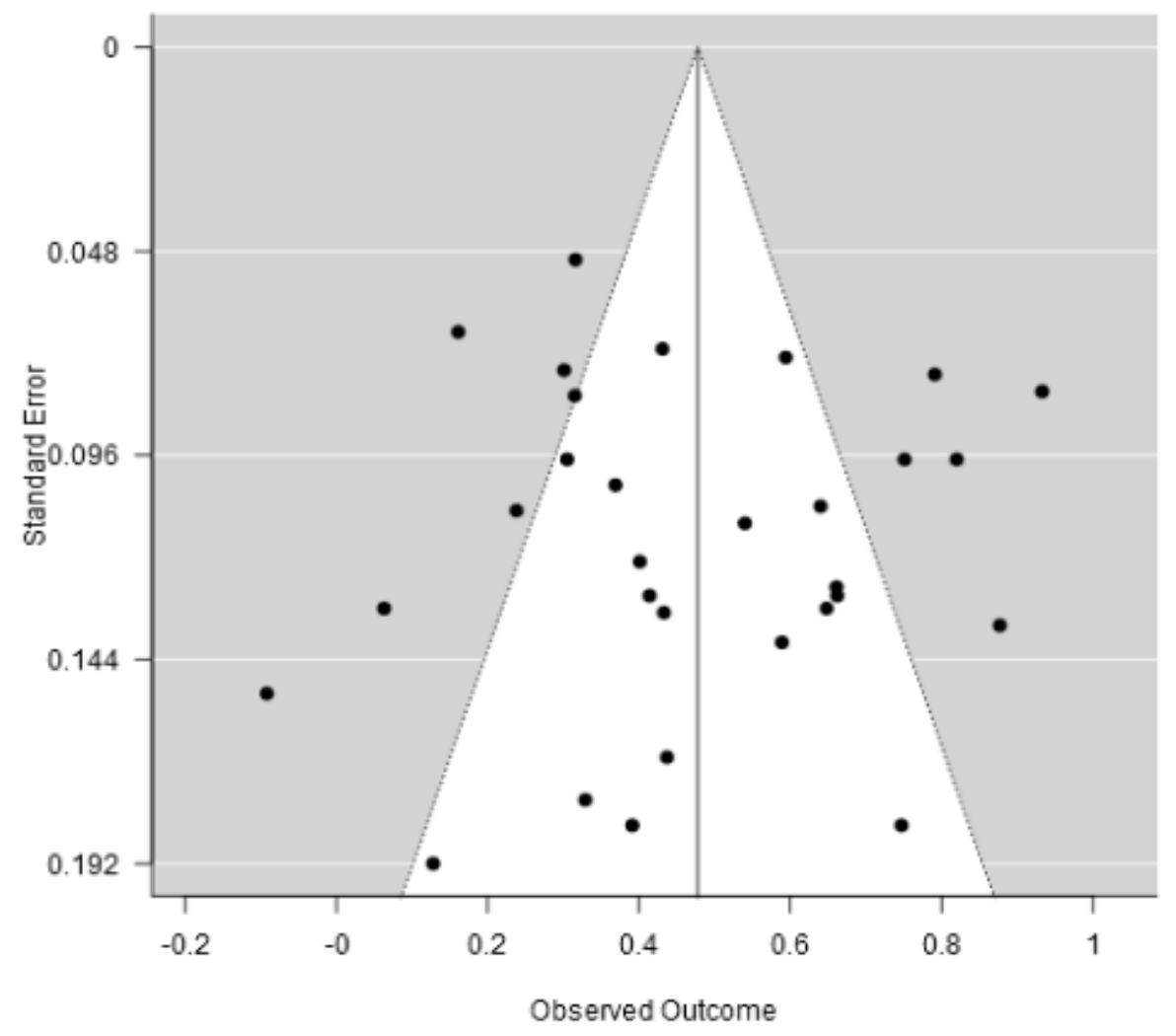

Figure 2. Funnel Plot Method for Detection of Publication Bias 
The Trim and Fill method as shown in Figure 3 shows the comparison between the summary effect before being analyzed and the summary effect after being analyzed with Trim and Fill. Based on the results of the analysis using this method shows that there is no shift in the value of the results of the analysis, or it can be said that the two results of the summary effect are the same. In addition, based on this method it appears that there was no increase in the number of analysis samples. Thus it can be concluded that in this research publication bias is not indicated.

Forest Plot

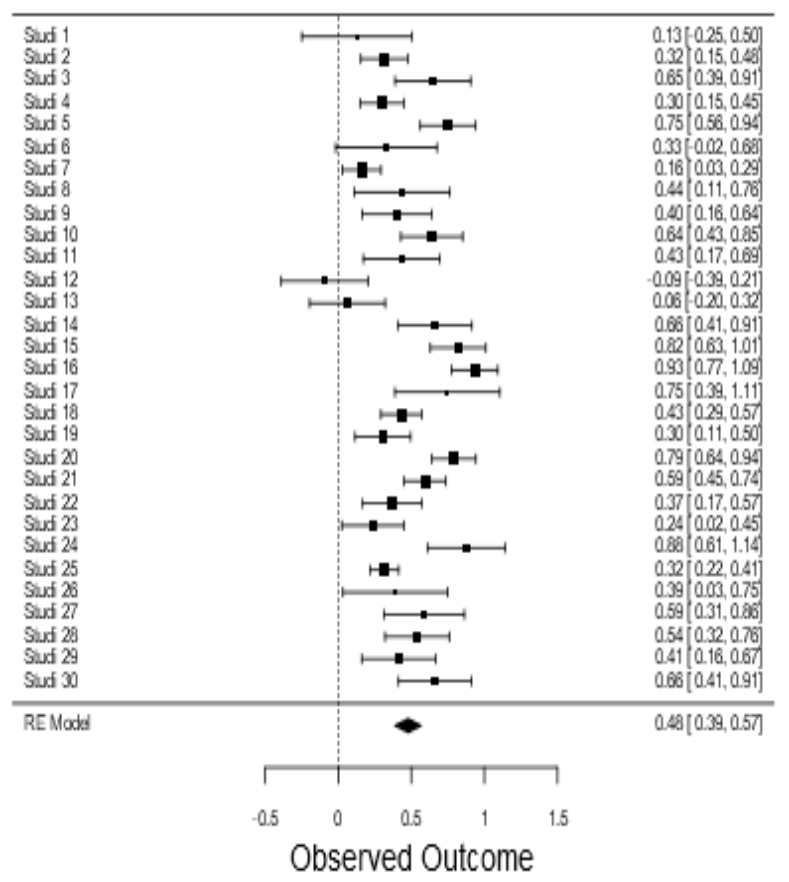

Funnel Plot

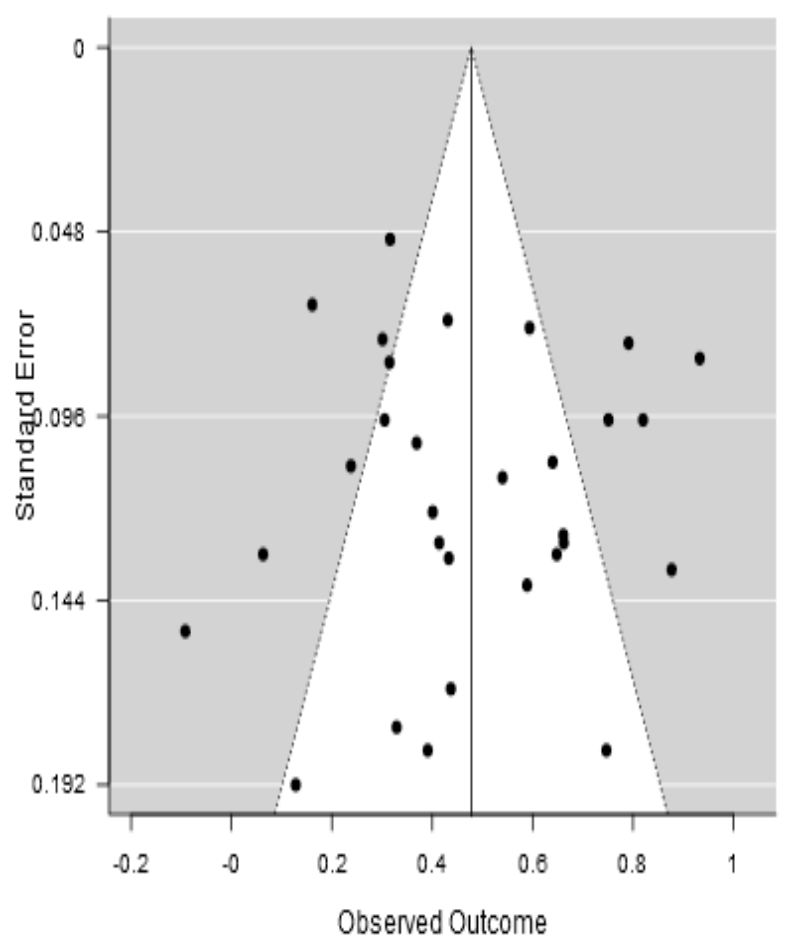

Figure 3. Trim-Fill Method for Detection of Publication Bias

\section{Conclusions and Implication}

A number of research results have reported that motivation has a significant relationship with teacher performance. Even so far, a lot of research in education has proven that motivation is a predictor of teacher performance. The significant relationship between these two variables can be an important reference for education administrators to plan strategies for increasing school productivity. Increasing school productivity can be done through motivating strategies specifically designed by management at the school level. Management interventions at the school level in motivating teachers are believed to improve teacher performance and school productivity. Although a number of research reports that intrinsic motivation is more effective in efforts to improve teacher performance than extrinsic motivation, administrators and managers of education at the school level need to examine and research in detail about aspects of the greatest needs of teachers as suggested by [68] namely a higher level of self-esteem, more autonomy, and a higher level of self-actualization. Various interventions in educational practice at the school level to improve teacher performance must be measurable and refer to supporting data from research findings. The research findings will be effectively utilized if the information presented in these findings is accurate and reliable. The accuracy of the information provided by the research findings is that they are free from publication bias and thus have potent benefits when applied to specific practices. The results of educational research that are free from publication bias will be effectively utilized when applied to targeted educational practices. Therefore, the detection of research publication bias will support the effectiveness of using the results of this research. Future research can be directed to compare meta-analysis between the effect of intrinsic motivation on teacher performance, and the effect of extrinsic motivation on teacher performance.

\section{REFERENCES}

[1] Maslow, A. H. (1943). A theory of human motivation. Psychological Review, 50(4), 370-396. https://doi.org/10.10 37/h0054346

[2] McGregor, D. M. (1960). The human side of enterprise. McGraw-Hill. 
[3] Vroom, V. H. (1964). Work motivation. John Wiley \& Sons.

[4] McClelland, D.C. 1965. 'Toward a theory of motive acquisition', American Psychologist, 20(5): 321-333. https://doi.org/10.1037/h0022225

[5] Herzberg, F. (1968). One more time: How do you motivate employees? Harvard Business Review, 40(1), 53-62. https://kyleshulfermba530.weebly.com/uploads/2/3/4/5/234 54770/one_more_time_-_how_do_you_motivate_employee s.pdf

[6] Locke, E. A. (1968). Toward a theory of task motivation and incentives. Organizational Behavior and Human Performance, 3(2), 157-189. http://dx.doi.org/10.1016/003 $0-5073(68) 90004-4$

[7] Alderfer, C. P. (1972). Existence, relatedness, and growth: Human needs in organizational settings. Free Press.

[8] Ryan, R. M., \& Deci, E. L. (2000c). Self-determination theory and the facilitation of intrinsic motivation, social development, and well-being. American Psychologist, 55(1), 68-78. https://doi.org/10.1037/0003-066X.55.1.68

[9] Elliot, A. J., \& Covington, M. V. (2001). Approach and avoidance motivation. Educational Psychology Review, 13(2), 73-92. https://doi.org/10.1023/a:1009009018235

[10] Tan, S. K., \& Rajah, S. (2019). Evoking work motivation in industry 4.0. SAGE Open, 9(4), 1-7.https://doi.org/10.1177/ 2158244019885132

[11] Tollefson, N. (2000). Classroom applications of cognitive theories of motivation. Educational Psychology Review, 12(1), 63-83. https://doi.org/10.1023/a:1009085017100

[12] Srivastava, S.K., \& Barmola, K.C. (2011). Role of motivation in higher productivity. Global Journal of Business Management, 5(1), 105-116. http://globalvisionpu b.com/journal-detail-issues.php?volumesno_id=25\&journal s_id=1\&volumes_id $=14$

[13] Bafadal, I., Wiyono, B.D., \& Sobri, A.Y. (2019). The implementation of school based management, and its effect on the teachers' work motivation and the school quality. Universal Journal of Educational Research, 7(9), 2021-2026. https://doi.org/10.13189/ujer.2019.070925

[14] Greenfield, W., \& Blase, J. J. (1981). Motivating Teachers: Understanding the Factors that Shape Performance. NASSP Bulletin, 65(448), 1-10. https://doi.org/10.1177/019263658 106544801

[15] Kanfer, R., Chen, G., \& Pritchard, R.D (2008). Work motivation: Past, present, and future. Routledge.

[16] Pritchard, R.D., \& Ashwood, E.L. (2007). Managing Motivation: A managers' guide to diagnosing and improving motivation. LEA/Psychology Press.

[17] Katz, I., \& Shahar, B.-H. (2015). What makes a motivating teacher? Teachers' motivation and beliefs as predictors of their autonomy-supportive style. School Psychology International, 36(6), 575-588. https://doi.org/10.1177/0143 034315609969

[18] Good, T. L., \& Lavigne, A. L. (2014). Issues of teacher performance stability are not new: Limitations and possibilities. Education Policy Analysis Archives, 23(2), 1-16. http://dx.doi.org/10.14507/epaa.v23.1916
[19] Eastridge, H. E. (1976). Student evaluation and teacher peformance. NASSP Bulletin, 60(401), 48-54. http://doi.org/10.1177/019263657606040110

[20] Larson, D. H. (1981). Advice for the principal: Dealing with unsatisfactory teacher performance. NASSP Bulletin, 65(442), 10-11. http://doi.org/10.1177/0192636581065442 03

[21] Larson, R. (1984). Teacher performance evaluation-What are the key elements? NASSP Bulletin, 68(469), 13-18. http://doi.org/10.1177/019263658406846902

[22] Lehman, L. E. (1989). Practical motivational strategies for teacher performance and growth. NASSP Bulletin, 73(520), 76-80. http://doi.org/10.1177/019263658907352013

[23] Lempesis, C. (1984). Peer observation improves teacher performance. NASSP Bulletin, 68(471), 155-156. http://doi.org/10.1177/019263658406847126

[24] Selmes, C. (1986). Teacher evaluation in the classroom. Educational Management \& Administration, 14(3), 191-196. http://doi.org/10.1177/174114328601400304

[25] Goodwin, B., \& Slotnik, W. J. (2019). Debunking the myth of the teacher performance plateau. Phi Delta Kappan, 100(7), 56-61. http://doi.org/10.1177/0031721719841340

[26] Steinberg, M. P., \& Kraft, M. A. (2017). The sensitivity of teacher performance ratings to the design of teacher evaluation systems. Educational Researcher, 46(7), 378396. http://doi.org/10.3102/0013189x17726752

[27] Huitt, W.G., \& Monetti, D.M. (2017). Openness and the transformation of education and schooling. In: Jhangiani, R.S and Biswas, D.R. (Eds.) Open: The philosophy and practices that are revolutionizing education and science (pp. 43-65). Ubiquity Press. https://doi.org/10.5334/bbc.d

[28] Jones, J., Jenkin, M., Lord, S. (2006). Developing Effective Teacher Performance. Paul Chapman Publising.

[29] Armstrong, M. (2000). Performance Management. Kogan Page.

[30] Rivai, V., \& Basri, A.FM. (2005). Performance appraisal: Sistem yang tepat untuk menilai kinerja karyawan dan meningkatkan daya saing perusahaan [Performance appraisal: The right system to assess employee performance and improve company competitiveness]. Raja Gravindo Persada.

[31] Brumback, G. B. (1988). Some ideas, issues and predictions about performance management. Public Personnel Management, 17(4), 387-402. http://doi.org/10.1177/00910 2608801700404

[32] Motowidlo, S. J., \& Van Scotter, J. R. (1994). Evidence that task performance should be distinguished from contextual performance. Journal of Applied Psychology, 79(4), 475480. https://doi.org/10.1037/0021-9010.79.4.475

[33] Retnawati, H., Apino, Kartianom, Djidu, \& Anazifa. (2018). Pengantar Analisis Meta [Introduction to meta-analysis]. Parama Publishing.

[34] Yensy, N. A. (2010). Pengaruh kompensasi dan motivasi terhadap kinerja guru di SMA Negeri 2 Argamakmur Bengkulu Utara [The effect of compensation and motivation on teacher performance in SMA Negeri 2 Argamakmur Bengkulu Utara]. Jurnal Kependidikan Triadik, 30(1), 33-42. 
http://repository.unib.ac.id/262/

[35] Uche, A. L., Fiberesima, D., \& Christiana, O. (2011). Relationship between motivational factors and teachers' performance on the job in Ogba/Egbema/Ndoni Local Government Area, of Rivers State. Mediterranean Journal of Social Sciences, 2(5), 22-26. http://www.richtmann.org/j ournal/index.php/mjss/article/view/10894

[36] Bestiana, R. (2012). Hubungan kepuasan kerja, motivasi dan komitmen normatif dengan kinerja guru SMPN 1 Rantau Selatan - Labuhan Batu [The relationship of job satisfaction, motivation, and normative commitment with the teacher performance of SMPN 1 Rantau Selatan - Labuhan Batu]. Jurnal Tabularasa PPs Unimed, 9(2), 187-200. http://digilib.unimed.ac.id/686/

[37] Tetuko, B. (2012). Pengaruh motivasi kerja, budaya organisasi, kepemimpinan kepala sekolah terhadap kepuasan kerja dan kinerja guru SMA Swasta di Kabupaten Grobongan [The influence of work motivation, organizational culture, principal's leadership on job satisfaction and performance of private high school teachers in Grobongan Regency]. Educational Management, 1(2), 129-134.

https://journal.unnes.ac.id/sju/index.php/eduman/article/vie $\mathrm{w} / 818$

[38] Wardana, D. S. (2013). Motivasi berprestasi dengan kinerja guru yang sudah disertifikasi [Achievement motivation with the performance of teachers who have been certified]. Jurnal Ilmiah Psikologi Terapan, 1(1), 98-109. http://ejournal.umm.ac.id/index.php/jipt/article/viewFile/13 $61 / 1456$

[39] Samudi. (2013). Hubungan motivasi kerja dan kemampuan penguasaan materi dengan kinerja guru [The relationship between work motivation and material mastery ability with teacher performance]. Jurnal Aksioma Ad-Diniyyah, 1(2), 70-84.

https://www.semanticscholar.org/paper/HUBUNGAN-MO TIVASI-KERJA-DAN-KEMAMPUAN-PENGUASAANSamudi/01e2056af04fcefa365513890ea4fc645067e5d6

[40] Saragi, A. S. (2014). Pengaruh budaya sekolah, kepuasan kerja, dan motivasi kerja terhadap kinerja guru SMA Negeri di Kota Binjai [The influence of school culture, job satisfaction, and work motivation on the performance of senior high school teachers in the City of Binjai]. Jurnal Pendidikan dan Kepengawasan, 2(2), 33-49. https://jurnal.unimed.ac.id/2012/index.php/jpdk/article/vie $\mathrm{w} / 7958$

[41] Cholil, M. (2014). Pengaruh kepemimpinan kepala sekolah dan motivasi kerja terhadap kinerja guru di SMP Muhammadiyah Ngawi [The influence of school principal leadership and work motivation on teacher performance in SMP Muhammadiyah Ngawi]. Jurnal Ilmiah STKIP PGRI Ngawi, 13(1), 92-101.https://lib.unnes.ac.id/29306/1/14014 12506.pdf

[42] Samaeng, A. (2015). Kompensasi, motivasi berprestasi dan kinerja mengajar guru SMP di Yala Thailand Selatan [Compensation, achievement motivation and teaching performance of junior high school teachers in Yala, Southern Thailand]. Jurnal Administrasi Pendidikan, 22(2), 13-22.

file://C:/Users/USER/AppData/Local/Temp/5385-10700-1 -PB.pdf
[43] Maharani, D. (2015). Pengaruh perilaku kepemimpinan kepala sekolah dan motivasi kerja terhadap kinerja mengajar guru TK [The influence of the principal's leadership behavior and work motivation on the teaching performance of kindergarten teachers]. Jurnal Administrasi Pendidikan, 22(1), 102-113. https://ejournal.upi.edu/index.php/JAPSPs/ article/view/5924

[44] Dewi, T. A. (2015). Pengaruh profesionalisme guru dan motivasi kerja terhadap kinerja guru ekonomi SMA Se-Kota Malang [The influence of teacher professionalism and work motivation on the performance of senior high school economics teachers in Malang]. Jurnal Pendidikan Ekonomi UM Metro, 3(1), 24-35. file://C:/Users/USER/AppData/Lo cal/Temp/148-250-1-SM.pdf

[45] Wibowo, D. H. (2015). Motivasi berprestasi dalam kaitannya dengan kinerja guru [Achievement motivation in relation to teacher performance]. Scholaria, 5(3), 65 - 74. https://doi.org/10.24246/j.scholaria.2015.v5.i3.p65-74

[46] Sampurno, D., \& Wibowo, A. (2015). Kepemimpinan kepala sekolah, lingkungan kerja, motivasi kerja, dan kinerja guru di SMK Negeri 4 Pandeglang [Principal's leadership, work environment, work motivation, and teacher performance in SMK 4 Pandeglang]. Jurnal Pendidikan Ekonomi dan Bisnis, 3.pp.165-180.

[47] Irlan. (2016). Pengaruh kepemimpinan dan motivasi kerja terhadap kinerja guru SDN di Kecamatan Singingi [The influence of leadership and work motivation on the performance of public primary school teachers in Singingi District]. Jurnal Ilmu Pendidikan Sosial, Sains, dan Humaniora, 2(3), 207-2015.http://ejournal.uin-suska.ac.id/i ndex.php/suaraguru/article/view/2658

[48] Kodariah, W., Herawan, E., Sutrasih, C. (2016). Supervisi Akademik Kepala Sekolah, Motivasi Berprestasi Guru, dan Kinerja Mengajar Guru [Principal's Academic Supervision, Teacher Achievement Motivation, and Teacher Teaching Performance]. Jurnal Administrasi Pendidikan, Vol.XXIII No.2.pp.123-133.

[49] Hadi, I. S. (2016). Pengaruh iklim organisasi dan motivasi mengajar terhadap kinerja profesional guru SMA, SMK, MA Muhammadiyah di Kabupaten Kudus [The influence of organizational climate and teaching motivation on the professional performance of the senior high school, vocational school, and primary school teachers in Kudus Regency]. Quality, 4(1), 199-216. https://journal.iainkudus. ac.id/index.php/Quality/article/view/2166

[50] Rahun, E., \& Kailola, L. (2016). Hubungan kepemimpinan kepala sekolah dan motivasi kerja dengan kinerja guru pada SMK Negeri Putussibau-Kapuas Hulu [The relationship between the principal's leadership and work motivation with teacher performance of state Vocational School in Putussibau-Kapuas Hulu]. Jurnal Manajemn Pendidikan UKI, 5(1), 27-42. http://ejournal.uki.ac.id/index.php/jmp/art icle/view/332

[51] Ramlanto, Soewarto, H., \& Widodo, S. (2017). The correlation between organizational culture, transformational leadership and work motivation to teachers' motivation to teachers'. International Journal of Managerial Research and Research, 5(4), 22-28.https://www.arcjournals.org/internati onal-journal-of-managerial-research-and-research/volume-5 -issue $-4 / 5$

[52] Nasrun, \& Ambarita, D. (2017). The effect of organizational 
culture and work motivation on teachers performance of public senior high school in Tebing Tinggi. Advances in Social Science, Education and Humanities Research, 118(1), 320-326. https://doi.org/10.2991/icset-17.2017.53

[53] Risaldin. (2017). Hubungan lingkungan kerja dan motivasi kerja dengan kinerja guru SD Negeri di Kecamatan Wawotobi Kabupaten Konawe [Relationship between work environment and work motivation with the teacher performance of the public primary school in Wawotobi District Konawe Regency]. WAKAPENDIK, 2(6), 1-13. http://ojs.uho.ac.id/index.php/wakapendikips/article/view/2 510

[54] Hardono, Haryono, \& Amin, Y. (2017). Kepemimpinan kepala sekolah, supervisi akademik, dan motivasi kerja dalam meningkatkan kinerja guru [Principal's leadership, academic supervision, and work motivation in improving teacher performance]. Educational Management, 6(1), 26-33.

https://docplayer.info/72221787-Educational-managementkepemimpinan-kepala-sekolah-supervisi-akademik-dan-mo tivasi-kerja-dalam-meningkatkan-kinerja-guru.html

[55] Ardiana, T. E. (2017). Pengaruh motivasi kerja guru terhadap kinerja guru akuntansi SMK di Kota Madiun [The influence of teacher's work motivation on the performance of vocational accounting teachers in Madiun City]. Jurnal Akuntansi dan Pajak, 17(2), 14-23.https://jurnal.stie-aas.ac. id/index.php/jap/article/view/11

[56] Hafid, M. (2017). Pengaruh motivasi dan kompetensi guru terhadap kinerja guru sekolah dan madrasah di lingkungan pondok pesantren salafiyah syafi'iyah sukorejo [The influence of teacher motivation and competence on the performance of madrasa teachers in Pondok Pesantren Salafiyah Syafi'iyah Sukorejo]. Jurnal Pendidikan Islam Indonesia, 1(2), 293-314. https://ojs.pps-ibrahimy.ac.id/ind ex.php/jpii/article/view/55

[57] Firmawati, Yusrizal, \& Usman, N. (2017). Pengaruh kepemimpinan kepala sekolah dan motivasi kerja terhadap kinerja guru [The influence of the principal's leadership and work motivation on teacher performance]. Jurnal Magister Administrasi Pendidikan, 5(3), 167-171.http://jurnal.unsyia h.ac.id/JAP/article/view/9025

[58] Mas'ud. (2017). Pengaruh kompetensi kepala sekolah, motivasi dan kompetensi guru terhadap kinerja guru serta implikasinya pada kompetensi lulusan [The effect of the principal's competence, motivation and teacher competence on teacher performance and its implications for graduate competencies]. Kontigensi. 5(2), 122-131. https://zenodo.or $\mathrm{g} / \mathrm{record} / 3375311$

[59] Gala, I., Ramadhan, A., \& Rede, A. (2017). Pengaruh pelatihan dan motivasi kerja terhadap kinerja mengajar guru IPA di SMP Se-Kota Poso [The effect of training and work motivation on the teaching performance of science teachers in Poso City Middle School]. E-Jurnal Mitra Sains, 5(2), 58-66.

https://media.neliti.com/media/publications/153678-ID-pen garuh-pelatihan-dan-motivasi-kerja-te.pdf

[60] Setiawan, E. (2018). Kontribusi Kompetensi Pedagogik dan Motivasi Kerja terhadap Kinerja Mengajar Guru [Contribution of Pedagogic Competence and Work Motivation to Teacher Teaching Performance]. Al Hikmah: Indonesian Journal of Early Childhood Islamic Education, 2(1), 43-58. http://journal.iaialhikmahtuban.ac.id/index.php /ijecie/article/view/22

[61] Wahyudi, R., Poernomo, D., \& Puspitaningtyas, P. (2018). Effect of information technology, satisfaction and motivation to teacher performance. The International Journal of Social Sciences and Humanities Invention, 5(1), 4370-4378.

file://C:/Users/USER/AppData/Local/Temp/1068-Article\% 20Text-2055-1-10-20180129.pdf

[62] Yenny. (2018). Pengaruh kompetenti, motivasi dan disiplin kerja terhadap kinerja guru pada yayasan pendidikan Imanuel Palu [Influence of competence, motivation and work discipline on teacher performance at the Immanuel Palu educational foundation]. E-Jurnal Katalogis. 6(2), 98-105.

http://jurnal.untad.ac.id/jurnal/index.php/Katalogis/article/v iew/10098

[63] Jihad, Murniati, \& Yusrizal. (2019). Hubungan motivasi kerja dan supervisi kepala sekolah dengan kinerja guru SMP Negeri di Kecamatan Babahrot Aceh Barat Daya [The relationship between work motivation and principal's supervision and performance of the teacher in state junior high schools in Babahrot Sub-district, Aceh Barat Daya]. Jurnal Magister Administrasi Pendidikan Pascasarjana Universitas Syiah Kuala, 7(1), 7-12.http://jurnal.unsyiah.ac .id/JAP/article/view/13176

[64] Evans, J.D. (1996). Straightforward statistics for the behavioral sciences. Pacific Grove.

[65] Winardi. (2009). Manajemen perilaku organisasi [organizational behavior management]. Kencana.

[66] Dickersin, K. (1990). The existence of publication bias and risk factors for its occurens. JAMA, 263(10), 1385-1389. https://jamanetwork.com/journals/jama/article-abstract/380 963

[67] Song, F., Hooper, L., \& Loke, Y. (2013). Publication bias: what is it? How do we measure it? How do we avoid it? Open Access Journal of Clinical Trials, 3(5), 71-81. https://doi.org/10.2147/OAJCT.S34419

[68] Anderson, M. B. G., \& Iwanicki, E. F. (1984). Teacher motivation and its relationship to burnout. Educational Administration Quarterly, 20(2), 109-132. https://doi.org/10.1177/0013161x84020002007 